\title{
Recovery of Vanadium and Lanthanides from the Processed Carbonate-Rich Latosol of Abu Thor Locality, Southwestern Sinai, Egypt
}

\author{
Enass M. El-Sheikh ${ }^{1}$, Saadia A.Ali ${ }^{2}$, Reda A. Ghazala ${ }^{1,}$ Abd Elaziz Abdelwarith ${ }^{1}$, and \\ Fatma salem*1 \\ 1.Nuclear Materials Authority, P.O. Box 530 El-Maadi, Cairo, Egypt \\ 2. Chemistry Department- College for Women of Art, Science and Education- \\ Ain Shams University
}

\begin{abstract}
In a previouswork, chemical processing of carbonate-rich latosol of Abu Thor locality have successfully recovered both of $\mathrm{U}$ and $\mathrm{Cu}$ contents by applying two successive steps of leaching processes. From the latter, the remaining two metal values; namely V and Lns were left behind in the spent residue. The latter represents the feed material of the present work for $\mathrm{V}(1050 \mathrm{ppm})$ and Lns (649 ppm ) recovery.

The work involves selective leaching process for $\mathrm{V}$ using alkali breakdown with Sodium hydroxide $(\mathrm{NaOH})$ followed by its precipitation $\operatorname{as}_{2} \mathrm{O}_{5}$. The Lanthanides (Lns) left behind was then leached by using sulfuric acid followed by its precipitation as a highly pure Lns oxalate.
\end{abstract}

Key Words: Recovery, vanadium, lanthanides, sulfuric acid, sodium hydroxide.

\section{Introduction}

Abu Thor locality of west central Sinai area is an example of the radioactive anomalies that are associated with carbonate- rich latosol which have been mainly derived from the Lower Carboniferous siltstone, clays, shales of the middle dolomitic -limestone series of Um Bogma Formation (ElAassy et al. ,1886). These authors concluded that the latosol at both Allouga and Abu Thor localities are of good uranium potentiality in which some secondary uranium minerals together with some other minerals of $\mathrm{Cu}, \mathrm{V}$, and Lns are visible besides the famous Fe-Mn deposits in different concentrations.

Generally, vanadium could actually be leached from its ores by either acidic or alkaline $\left(\mathrm{NaOH}\right.$ or $\mathrm{Na}_{2} \mathrm{CO}_{3}$ ) breakdown as well as salt roasting with $\mathrm{NaCl}$ (fluxing). The produced pentavalent vanadium salt undergoes $\mathrm{H}_{2} \mathrm{O}$ leaching to dissolve its vanadium content. The solvent extraction or ion exchange and direct precipitation techniques were applied for the recovery of vanadium from the prepared leach liquor. Vanadium is expected to be in the 
form of $\mathrm{VO}_{3}(\mathrm{OH})_{2}$ and $\mathrm{VO}_{4}^{-3}($ Greenwood, et al.,1984).Fig.(1) represents the general flowsheet for chemical processing of vanadium from the major vanadium- bearing materials, (Eatough et al., 1984). On the other hand, direct acid leaching has been used in commercial leaching procedures. Haoran et al. (2008) used acidic leaching with $\mathrm{H}_{2} \mathrm{SO}_{4}$ to extract V from vanadium bearing-clay mineral. The leached vanadium was then precipitated with $\mathrm{NH}_{4} \mathrm{Cl}$ after removing the associated impurities via their precipitation with $\mathrm{NaOH}$. According to Zhang et al.(2011) the salt roasting leaching process was devised to extract $\mathrm{V}$ from the oxidized carnotite ore in the thirties of the last Century. It was applied to produce water soluble $\mathrm{V}$ products and to separate between $\mathrm{V}$ and $\mathrm{U}$. The salt roasting process was performed by mixing the ground ore (-10 mesh size) with $6-10 \%$ of $\mathrm{NaCl}$ and roasting the mixture at a temperature ranging from 825 to $850^{\circ} \mathrm{C}$ for 1 to $2 \mathrm{~h}$ in a multiple roaster. The calcined material was then cooled rapidly and leached with $\mathrm{H}_{2} \mathrm{O}$ to extract the water soluble sodium vanadate. The remained residue was further treated with dilute acid to dissolve its $\mathrm{U}$ content and additional acid-soluble V compounds,(Holloway and Etsell, 2002).

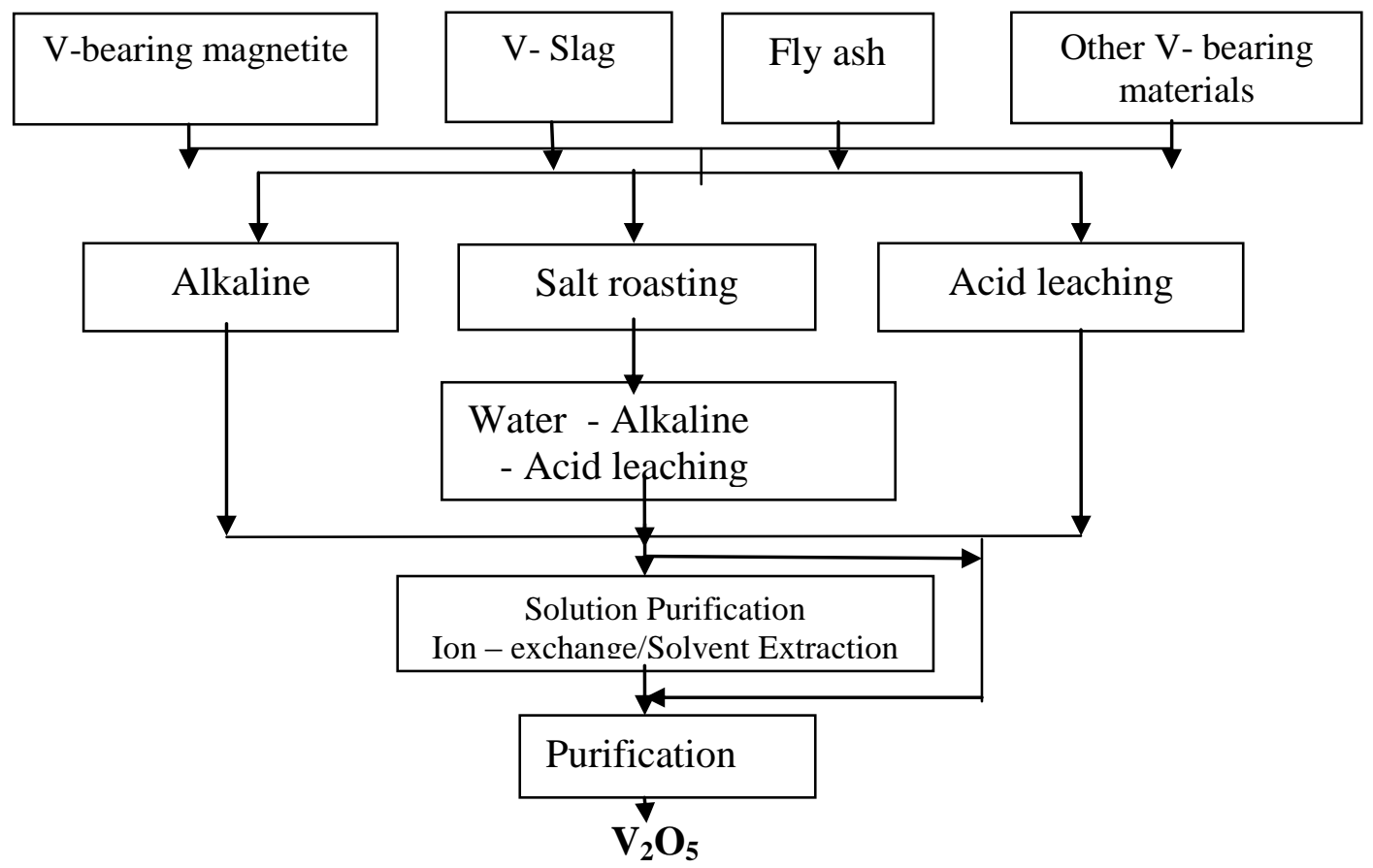

Fig. (1): Represents the general flowsheet for chemical processing of vanadium from the major vanadium- bearing materials 
With respect to Lns recovery, several methods that industrially be applied have been studied for the breakdown of the most common lanthanides minerals via acidic or alkaline breakdown. The sulfuric acid method has been depending on the acid/ore ratio, temperature and concentration. On the other hand, alkali breakdownacid baking with sulfuric acid is a very common process. The powdered ore is mixed with concentrated sulfuric acid and baked at temperatures between 200 and $400{ }^{\circ} \mathrm{C}$ for several hours. The resulting cake is leached with water to dissolve Lns as sulfates. The lanthanides recovery based on lanthanides double sulfates precipitation or Lns oxalates,(Marczenco, 1976).

In the present work, the starting feed material is the spend residue obtained after applying two successive leaching processes for selective recovery of $U$ and Cufrom the original raw material of carbonate-rich latosol occurring at Abu Thor locality of Southwestern Sinai mineralization, (El-Sheikh et al. , 2015). Selective uranium leaching was achieved by using urea while copper was subsequently and relatively leached with mixed solutions of ammonium hydroxide and ammonium carbonate. The optimum leaching conditions for uranium include urea solutions of $60 \mathrm{~g} / \mathrm{L}$ concentration at room temperature. for $90 \mathrm{~min}$. in a S/L ratio of $1 / 5$. The uranium leaching efficiency was found to attain up to 97.5\%. The uranium leached ore sample was then subjected to almost complete $\mathrm{Cu}$ dissolution (98.9\%) using the optimum condition of $120 \mathrm{~g} / \mathrm{L}$ ammonia solution and $35 \mathrm{~g} / \mathrm{L}$ ammonium carbonate for 2 hours and in a S/L ratio of $1 / 5$ in (El-Sheikh et al. ,2015). The remaining two metal values; namely $\mathrm{V}$ and Lns which were left behind in the spent residue were found to assay 1050 and 649 ppm respectivelySo, the present work was directedto study the recovery of both $\mathrm{V}$ and Lnsmetal values from the spent residual material.These involved $\mathrm{V}$ recovery by alkaline leaching followed by classical acidic leaching procedures for Lns.

\section{Materials and Methods}

\subsection{Materials}

As previously mentioned, the starting feed material of the present work is the spend residue obtained after applying two successive leaching processes for selective recovery of $\mathrm{U}$ and Cufrom the original raw material of carbonate-rich latosolof Abu Thor locality at Southwestern Sinai El-Sheikh et al., Op. cited. This dried residue was subjectedto 
twosuccessive recovery procedures for $\mathrm{V}$ and Lns .The applied successive leaching procedures include, alkali breakdown of vanadium followed by classical acidic leaching for Lns.

\subsection{Methods}

\subsubsection{Alkali breakdown of vanadium}

For alkali breakdown of vanadium several leaching experiments have actually been performed including fusion with $\mathrm{NaOH}$ to optimize the relevant dissolution factors. In these experiments, a suitable weight of the working spent ore residue was mixed with a suitable weight of NaOHin a porcelain crucible for different time periods and different temperatures. The obtained melt was then cooled and washed with distilled water, filtered and made up to a volume. The interesting metal values were then analyzed in the filtrate to calculate the dissolution efficiency percent.

\subsection{Acidic leaching of lanthanides}

Several acidic leaching experiments were performed for recoveringLanthanidesfrom the spent ore residue free from vanadium by using sulfuric acid. Factors controlling leaching process such as; acid concentrations, effect of temperatureand effect of S/L ratio have been studied. At the end of each leaching experiment, the obtained aliquot filterate were analyzed for Lns to calculate theirleaching efficiency.

\subsubsection{Analytical procedures}

The content of the processed metal values ( $\mathrm{V}$ and Lns) whether in the spent ore residueor in the different stream solutions obtained during leaching and recovery steps were determined by proper techniques. Thus,Lns were spectrophotometrically determined by the chromogenic reagent Arsenazo-III (Merczenko, 1986)) while vanadium wasanalysed byusing atomic absorption spectrophotometry (AAS) model Unicam 969, England.

Finally, to insure the purity of the obtained metal concentratesthe environmental scanning electron microscope (ESEM) together with chemical analyses were used.

\section{Results andDiscussion}

\subsection{Recovery of vanadium and Lns}

Chemical composition(Table 1) of theoriginal carbonate-rich latosol ore material of $\mathrm{Abu}$ Thor locality reflects the carbonaceous nature of the raw material. Form the latter, andafter the recovery of $\mathrm{U}$ and $\mathrm{Cu}$, the dried residue was then subjected to two successive 
recovery procedures for $\mathrm{V}$ and Lns .Theapplied successive leaching procedures include, alkali breakdown of vanadium followed by classical acidic leaching for Lns.

Table (1): Chemical composition of the originallatosol technological raw ore sample( After El- Sheikh et al. ,2015).

\begin{tabular}{|c|c|c|c|}
\hline Component & wt.\% & Component & wt.\% \\
\hline $\mathrm{SiO}_{2}$ & 12.5 & $\mathrm{~K}_{2} \mathrm{O}$ & 0.42 \\
\hline $\mathrm{TiO}_{2}$ & 0.13 & $\mathrm{P}_{2} \mathrm{O}_{5}$ & 0.03 \\
\hline $\mathrm{Al}_{2} \mathrm{O}_{3}$ & 5.84 & $\mathrm{SO}_{4}$ & 2.07 \\
\hline $\mathrm{Fe}_{2} \mathrm{O}_{3}$ & 4.65 & $*$ L.O.I & 34.90 \\
\hline $\mathrm{MnO}$ & 3.33 & $\mathrm{CuO}$ & 9.65 \\
\hline $\mathrm{MgO}$ & 3.00 & $\mathrm{Cl}^{-}$ & 0.70 \\
\hline $\mathrm{CaO}$ & 24.73 & Total & $\mathbf{1 0 0 . 7}$ \\
\hline $\mathrm{Na} 2 \mathrm{O}$ & 0.04 & & ppm \\
\hline Trace element & $\mathbf{p p m}$ & Trace element & 159 \\
\hline $\mathrm{Ba}$ & 1311 & $\mathrm{~Pb}$ & 190 \\
\hline $\mathrm{V}$ & 789 & $\mathrm{Cr}$ & 801 \\
\hline $\mathrm{Ni}$ & 100 & $\mathrm{Sr}$ & 40 \\
\hline $\mathrm{Nb}$ & 34 & $\mathrm{Ga}$ & 330 \\
\hline $\mathrm{Zn}$ & 325 & $\mathrm{Zr}$ & 700 \\
\hline $\mathrm{Rb}$ & 102 & $\mathrm{U}$ & 24 \\
\hline $\mathrm{Cd}$ & 13 & $\mathrm{Co}$ & 456 \\
\hline $\mathrm{Y}$ & 200 & $\sum \mathrm{Lns}$ & \\
\hline
\end{tabular}

*L.O.I. $=$ loss on ignition at $1000^{\circ} \mathrm{C}$

\section{1.1 Recovery of vanadium}

Recovery of $\mathrm{V}$ from the study ore residue include two steps namely; alkali breakdown by using sodium hydroxide followed by vanadium precipitation.

\section{1.1.1 Alkali breakdown}

In this method, $\mathrm{NaOH}$ was mixed with the spent ore residue in different weight ratios and then allowed for heating at different temperatures for different times. After cooling, the fused cake was then dissolved in distilled water for $30 \mathrm{~min}$. to bring out the vanadium content in solutions to determine the dissolution efficiency. 


\section{i- Effect of spent ore residue $/ \mathrm{NaOH}$ reagentratio $(\mathrm{S} / \mathrm{R})$ :}

To study the effect of spent ore residue / $\mathrm{NaOH}$ ratio upon the dissolution efficiency of $\mathrm{V}$, a set of experiments were performed using ratios ranging from 1:1 to 1:5, while the other fusion conditions were fixed at $200{ }^{\circ} \mathrm{C}$ for $3 \mathrm{~h}$. The obtained results are given in Table (2).

Table (2): Effect of Ore/ $\mathrm{NaOH}$ ratio upon vanadium dissolution efficiency.

\begin{tabular}{|c|c|}
\hline Spent ore residue/NaOH ratio & V Dissolution Efficiency, \% \\
\hline $1 / 1$ & 80.18 \\
\hline $1 / 2$ & 86.36 \\
\hline $1 / 3$ & 98.79 \\
\hline $1 / 4$ & 98.86 \\
\hline $1 / 5$ & 98.82 \\
\hline
\end{tabular}

From this table, it can be concluded that the dissolution efficiency of vanadium increases with decreasing the spent residue / NaOHratio, this indicating its effective role on the ore breakdown. Thus, by decreasing the spent residue / $\mathrm{NaOH}$ ratio from 1/1 to $1 / 3$ the corresponding dissolution efficiencies increase from 80.2 to $98.8 \%$. Beyond $1 / 3$ spent oreresidue / NaOHratio, only a very slight steady increase in the dissolution efficiencies of vanadium has been achieved. Accordingly, spent ore residue / $\mathrm{NaOH}$ ratioof $1 / 3$ would be considered as optimum at which the leaching efficiency of vanadium attained $98.8 \%$.

\section{ii- Effect of fusion temperature:}

The effect of fusion temperature upon the dissolution efficiencies of vandium from spent ore residue, was studied in the range of 120 to $300{ }^{\circ} \mathrm{C}$. Other fusion conditions were fixed at spent ore residue / $\mathrm{NaOH}$ ratio of 1:3 and fusion time of $3 \mathrm{~h}$. The obtained results ,table(3) indicate that fusion temperature is the most important factor for spent ore residue breakdown. However, increasing the fusion temperature from 120 to $200^{\circ} \mathrm{Chas}$ a significant increase in $\mathrm{V}$ dissolution efficiency from 58.3 to $98.8 \%$.While at fusion temperature of 250 and $300{ }^{\circ} \mathrm{C}$ an adverse effect on the $\mathrm{V}$ dissolution efficiency takes place where it decreased to 94.39 and $92.12 \%$ respectively. This may be attributed to dissolution of many undesired impurities from the ore residueor the beginning of $\mathrm{V}$ hydrolysis. Thus, 200 ${ }^{\circ} \mathrm{C}$ was considered as the optimum fusion temperature. 
Table(3):Effect of fusion temperature upon vanadium dissolution efficiency.

\begin{tabular}{|c|c|}
\hline Temp., ${ }^{\circ} \mathrm{C}$ & $\begin{array}{ll}\text { V } & \text { Dissolution Efficiency, \% }\end{array}$ \\
\hline 120 & 58.31 \\
\hline 150 & 94.45 \\
\hline 200 & 98.79 \\
\hline 250 & 94.39 \\
\hline 300 & 92.12 \\
\hline
\end{tabular}

\section{iii- Effect of fusion time:}

The effect of fusion time upon the dissolution efficiency of vanadium from the spent ore residue was studied in the range of 1 to $5 \mathrm{~h}$. Other fusion conditions were fixed at a spent ore residue / $\mathrm{NaOH}$ ratioof 1:3 and fusion temperature of $200{ }^{\circ} \mathrm{C}$. The dissolution efficiency of the vanadium is given in table (4).

Table (4): Effect of fusion time upon vanadium dissolution efficiency .

\begin{tabular}{|c|c|}
\hline Time,h. & V Dissolution Efficiency, \% \\
\hline 1 & 55.24 \\
\hline 2 & 61.47 \\
\hline 3 & 98.79 \\
\hline 4 & 85.76 \\
\hline 5 & 61.34 \\
\hline
\end{tabular}

From the obtained results, it is clearly evident that increasing the fusion time from 1 to $3 \mathrm{~h}$ increases the dissolution efficiencyof vanadium from 55.2 to $98.8 \%$. On the other hand, further increase in the fusion time to 4 and $5 \mathrm{~h}$ has adversely affected the dissolution efficiency of vanadium due to the beginning of $\mathrm{V}$ hydrolysis.

Finally, from the foregoing results it can be concluded that, using fusion method is more convenient to bring out most of the vanadium content into solution. The obtained 
optimum conditions for dissolving $98.8 \%$ of the vanadium from spent ore residue can be summarized as following:

Fusion time

$: \quad 3 \mathrm{~h}$.

Fusion temperature

: $\quad 200{ }^{\circ} \mathrm{C}$

Spent ore residue / $\mathrm{NaOH}$ ratio : $\quad 1 / 3$

\subsubsection{Precipitation of vanadium}

To prepare a rich V leach liquor, $600 \mathrm{~g}$ of spent ore residuewas carefully mixed with $1800 \mathrm{~g} \mathrm{ofNaOH}$ and fused for $3 \mathrm{~h}$ at $200{ }^{\circ} \mathrm{C}$. The fused cake was then leached with $600 \mathrm{ml}$ distilled water to obtain the dissolved vanadateions. The obtained vanadate solution may contain small amounts of $\mathrm{V}^{4+}$, which can be quickly oxidized to $\mathrm{V}^{5+}$. This was accomplished by the addition of $30 \% \mathrm{H}_{2} \mathrm{O}_{2}$ to the prepared solution to oxidize $\mathrm{V}^{4+}$ to $\mathrm{V}^{5+}$.The $\mathrm{pH}$ of the latter solution was then adjusted to $\mathrm{pH} 8$ by using $30 \% \mathrm{H}_{2} \mathrm{SO}_{4}$ to precipitate $\mathrm{V}$. The latter precipitate has been subjected to calcinations at $800^{\circ} \mathrm{C}$ to form $\mathrm{V}_{2} \mathrm{O}_{5}$, Fig.(2).

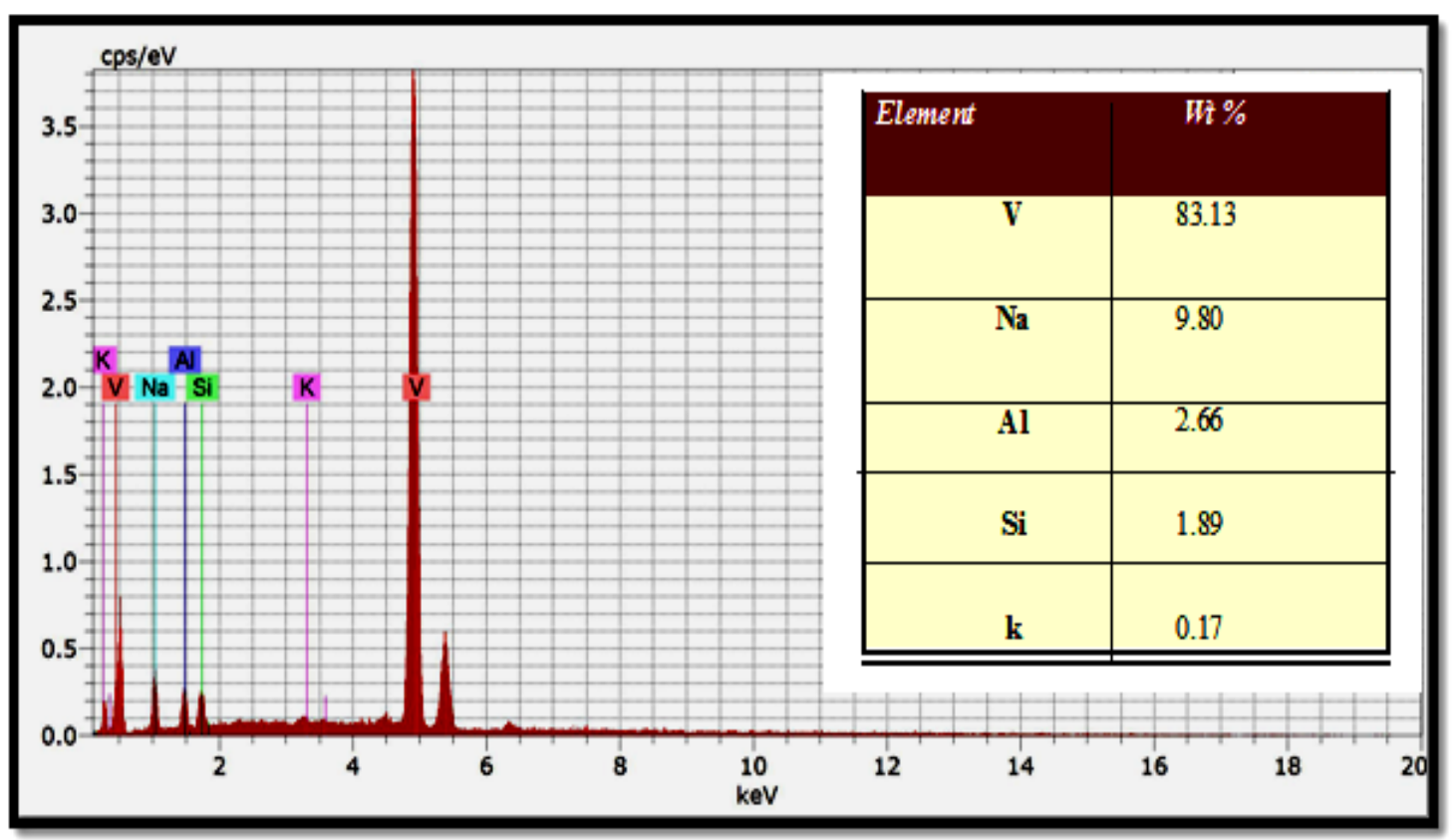

Fig.(2): ESEM- EDX analysis of the prepared $\mathrm{V}_{2} \mathrm{O}_{5}$. 


\section{1. 2. Recovery of Lns}

After removing of vanadium from the spent ore residue, acidic agitation leaching process by using sulfuric acid was performed to dissolve included Lns content.

\section{1. 2.1. Acidic leaching of Lns}

To optimize the leaching condition of Lns, the following leaching factors were studied.

\section{i.Effect of $\mathrm{H}_{2} \mathrm{SO}_{4}$ concentration}

The effect of $\mathrm{H}_{2} \mathrm{SO}_{4}$ acid concentration upon the leaching efficiency of Lns from spent ore residue free from vanadium was studied between 40 and $200 \mathrm{~g} / \mathrm{L}$, and the other leaching conditions as contact time ( $3 \mathrm{~h}$ )and solid / liquid ratio(1/3) at room temperature were fixed. The obtained results, Table (5), indicated that, the best acid concentration was $80 \mathrm{~g} / \mathrm{L}$ for leaching about $97 \%$ of Lns content. At the high acid concentration of $200 \mathrm{~g} / \mathrm{L}$, Lns leaching efficiency was decreased to about $87 \%$ due to the formation of Lns double sulfates.

Table (6): Effect of sulfuric acid concentration uponLns leaching efficiency.

\begin{tabular}{|c|c|}
\hline Conc. of sulfuric acid $\mathbf{g} / \mathbf{L}$ & LnsLeaching efficiency, $\%$ \\
\hline 40 & 65.89 \\
\hline 60 & 79.16 \\
\hline 80 & 97.11 \\
\hline 100 & 96.90 \\
\hline 200 & 87.45 \\
\hline
\end{tabular}

\section{ii. Effect of stirring time:}

For studying the effect of stirring time upon Lns leaching efficiency, a series of leaching experiments have been performed by varying the stirring time between 60 and $180 \mathrm{~min}$. The other leaching conditions were fixed at acid conc of $80 \mathrm{~g} / \mathrm{L}$, solid / liquid ratio of $1: 3$, at room temperature.Table (6).From the obtained results, it is noticed that by increasing the stirring time, the leaching efficiency of Lns increases and reaches its maximum value $96.18 \%$ at $120 \mathrm{~min}$. Increasing the leaching time to $180 \mathrm{~min}$., there is no marked increase in the leaching efficiency of Lns. 
Table (6): Effect of stirring time uponLns leaching efficiency.

\begin{tabular}{|c|c|}
\hline Effect of stirring time, min. & LnsLeaching efficiency, \% \\
\hline 60 & 70.25 \\
\hline 80 & 90.36 \\
\hline 120 & 96.18 \\
\hline 150 & 96.87 \\
\hline 180 & 97.11 \\
\hline
\end{tabular}

\section{iii. Effect of the solid / liquid ratio}

To study the effect of S/L ratio upon leaching efficiency of Lns a series of leaching experiments were performed at the solid / liquid ratio (S/L) range of 1:3, 1:4 and 1:5 at the fixed conditions of $80 \mathrm{~g} / \mathrm{L} \mathrm{H}_{2} \mathrm{SO}_{4}$, stirring time of $120 \mathrm{~min}$. at room temperature. The obtained results , Table(8) indicated that, at the $\mathrm{S} / \mathrm{L}$ ratio of $1 / 3$ to $1 / 5$, only slight increase in the leaching efficiencies of Lns takes place. Thus, 1/3 would be considered as the optimum $\mathrm{S} / \mathrm{L}$ ratio.

Table. (7): Effect of $\mathrm{S} / \mathrm{L}$ ratio uponLns leaching efficiency.

\begin{tabular}{|c|c|}
\hline Solid /liquid ratio & LnsLeaching efficiency, $\%$ \\
\hline $1: 3$ & 96.18 \\
\hline $1: 4$ & 97.08 \\
\hline $1: 5$ & 97.11 \\
\hline
\end{tabular}

Finally, from the foregoing acidic leaching study, it can be concluded that the optimum leaching conditions for dissolving $96.2 \%$ Lns content would be summarized as following: $\mathrm{H}_{2} \mathrm{SO}_{4}$ concentration:80 g/L

Stirring time: $120 \mathrm{~min}$.

Temp.: room

$\mathrm{S} / \mathrm{L}$ ratio: $1 / 3$

\section{1. 2.2. Precipitation of Lns}

To prepare a richLns leach liquor, $3000 \mathrm{~g}$ of spent ore residue free from Vwas subjected to sulfuric acid agitation leaching under the obtained leaching conditions. Avolume of 9 litter was obtained assying $208 \mathrm{mg} /$ LLns. To increase the concentration of 
Lns, this leach liquor was then subjected to evaporation process to reduce the volume to 3 liters in order to obtain a Lns- oxalate concentrate. The latter was accomplished by adjusting the $\mathrm{pH}$ of the solution to 4.5 , then by the addition of $10 \%$ oxalic acid ,Lns oxalate was precipitated at $\mathrm{pH} 1$. The obtained Lns oxalate precipitate was then calcined at $800{ }^{\circ} \mathrm{C}$ for $3 \mathrm{~h}$ and analyzed by using ESEM-EDEX techenique Fig.(3).

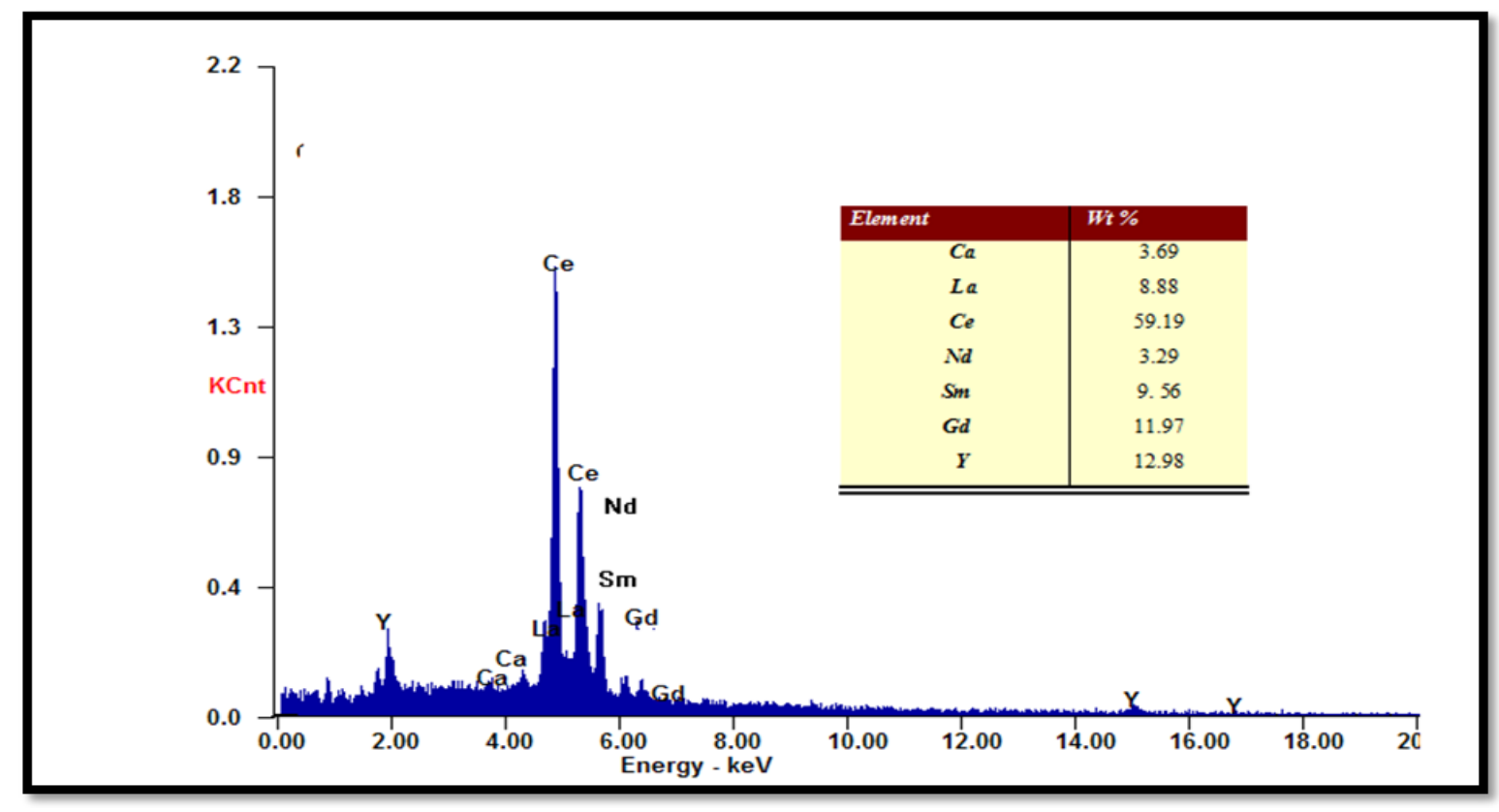

Fig.(3): ESEM- EDX analysis of the prepared Lnsoxide .

\section{Conclusion}

From the foregoing study, the following general conclusions can be summarized:

1- A procedure for separating $\mathrm{V}$ from the accompanying Lns can be achieved by breaking down the study spent ore residue by using $\mathrm{NaOH}$ at the optimum conditions of spent ore residue / $\mathrm{NaOH}$ ratio: $1 / 3,3 \mathrm{~h}$. fusion time and $200{ }^{\circ} \mathrm{C}$ fusion temperature .

2- A procedure for separating Lns from the spent ore residue free from Vcan be achieved by acidic leaching at the optimum conditions of $80 \mathrm{~g} / \mathrm{L} \mathrm{H}_{2} \mathrm{SO}_{4}$ concentration, $120 \mathrm{~min}$.Stirring time within $\mathrm{S} / \mathrm{L}$ ratio of : $1 / 3$ at room Temp.

\section{References}


Chen, X.Y. ,Lan, X.Z., Zhang, Q.L., Ma Hong, Z. and Zhou, J.,: Leaching vanadium by high concentration sulfuric acidfrom stone coal, Trans. Non Ferrous Met. Soc. China, 20, 123-126, (2010).

Coleman, C. F., Brown, K. B., Moore, J. G. and Cruse, D. F.: 1nd. Eng. Chem., Vol. 50, pp. 1756-1762, (1958).

Eatough, D.J., Eatough, N.L., Hill, M.W., Mangelson, N.F. and Hansen, L.D.,: Identification of VO2 in particles from theflue lines of oil fired power plants, Environmental Science andTechnology, 18, 124-126, (1984).

Enass M. El-Sheikh, Saadia A.Ali, Reda A. Ghazala' Abd Elaziz Abdelwarith, and Fatma salem: Leaching characteristics of uranium and copper from their mineralization in the carbonate rich latosol of Abu Thor locality, SW Sinai, Egypt, , Isotop\& RAD.RES, Vol.,47, Issue (2),231-246., (2015).

El Aassy, I., Botros, N. H., Abdel Razik, A., El Shamy, A. S., Ibrahim, S. K., Sherif, H. Y., Attia, K. E. and Moufei, A. A.): Report on proving of some radioactive occurrences in west central Sinai. Int. Rept. N.M.A., Cairo, Egypt, (1986).

Haoran, L., Yali, F., Jianglong, L., Xiaobing, L. and Zhuwei, D.,): Vanadium recovery from clay vanadium mineral using anacid leaching method, Rare Metals, 27, (2), 116-120,(2008).

Holloway, P. and Etsell, T.H.,:Recovery of vanadium from oil sands fly ash. In: Tanner, M.F., Riveros, P.A., Dutrizac, J.E., Gattrell, M., Perron, L. (Eds.), Vanadium, Geology, Processing and Applications, Proceedings of the International Symposium on Vanadium, Conference of Metallurgists, Montr_eal, Canada, August11-14, 227-242., (2002).

Li, X., Wei, C., Deng, Z., Li, M., Li, C. and Xu, H.,:Acid leaching of vanadium from a vanadium residue, AdvancedMaterials Research, 402, 243-248., (2012).

Marczenco Z.,: Spectrophotometric Determination of Elements), John Wiley and Sons, New York , p.469. (1976).

Merczenko, Z.: Separation and Spectrophotometric Determination of Elements, Harwood, New York, P.708, (1986).

Woody, R.G. and Georg, D.R.,: Acid leaching of uranium ores in uranium ore processing by J.W. Clegg and D.D. Foley, Eed., Addison Wesley, Reading, Mass, USA, (1958).

Zhang, X., Yang, K. Tian ,X. and Qin, W.,: Vanadium leaching from carbonaceous shale using fluosilicic acid,International Journal of Mineral Processing, 100 , 184-187, (2011). 


\section{ملخص البحث باللغة العربية}

استخلاص الفانديوم واللانثيندات من التربة اللاتر اتيه سابقه المعالجه الغنية بالكربونات موقع أبو ثور

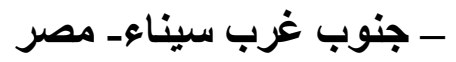

إيناس محمد الثيخ1، سعدية احمد على2 ، رضا عبد الثهيد غزالة1، عبد العزيز عبد الوارث 1، فاطمة سالم حسن

ا - هيئة المواد النووية

r-بكلية البنات للاداب و العلوم التربية-جامعة عين شمس لمس

بعد دراسة المعالجة الكيميائية لاستخلاص اليور انيو و النحاس التى تمت سابقا على خام التربة التية

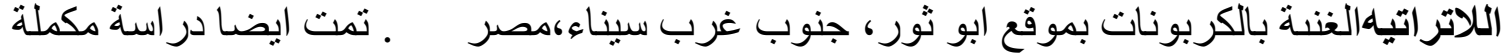

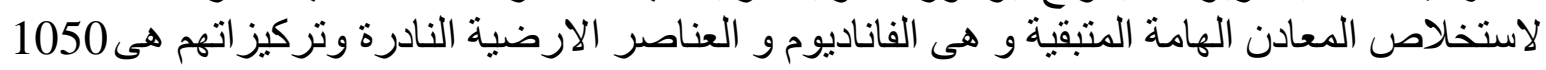

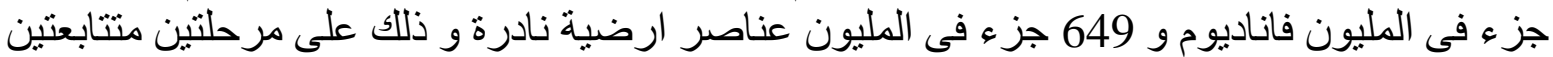

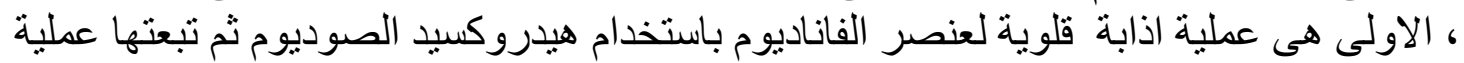

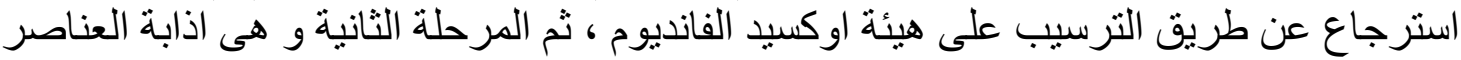

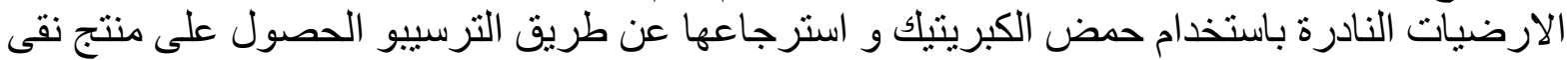

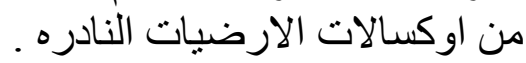

